\title{
An Investigation Of Foreign Language Classroom Anxiety And Its Relationship With Students' Achievement
}

\author{
Riffat-un-Nisa Awan, University of Sargodha, Pakistan \\ Musarrat Azher, University of Sargodha, Pakistan \\ Muhammad Nadeem Anwar, University of Sargodha, Pakistan \\ Anjum Naz, University of Sargodha, Pakistan
}

\begin{abstract}
The present study examines anxiety in English undergraduate classes with regard to the type of situations that provoke anxiety during different stages of the learning process and the relationship of anxiety with learners' achievement. Participants of the study include 149 undergraduates enrolled in second and sixth semester of different departments of University of Sargodha who are learning English as a foreign language. The questionnaire used in this study is the abbreviated form of Foreign Language Classroom Anxiety Scale (FLCAS). An inventory is also used to determine different situations that provoke anxiety. Finally, students' GPA in English classes is taken to find its relationship with language anxiety. The results show that language anxiety and achievement are negatively related to each other. It is also found that female students are less anxious in learning English as a foreign language than male students. 'Speaking in front of others' is rated as the biggest cause of anxiety followed by 'worries about grammatical mistakes', 'pronunciation' and 'being unable to talk spontaneously'. It is suggested that the classroom environment should be encouraging and motivating. Moreover, teachers need to deal with anxiety-provoking situations carefully.
\end{abstract}

Keywords: Language Anxiety, Foreign Language Learning, Achievement

\section{INTRODUCTION}

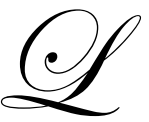

earning English as a foreign language has always been a problematic area for Pakistani students where they are exposed to English only in a language class. Most of the learners express their fears and a feeling of uneasiness against learning English as a foreign language. The feeling of anxiety can provoke many problems in the acquisition, retention and production of the language (MacIntyre and Gardner (1991a) which ultimately affects their grades, as compared to their more relaxed peers. Foreign language classroom anxiety (FLCA) is still considered to be a relatively new and developing area within foreign language research (Piniel, 2006) and in spite of the growing number of research dealing with foreign language anxiety (FLA), there is a limited number of studies involving students at the undergraduate level in Pakistan. Hence, the present research aims to investigate the causes that provoke anxiety during different stages of the learning process in a classroom situation and the relationship of anxiety with learners' achievement at the undergraduate level. The researchers have intended to relate anxiety with factors such as learners' gender, their background and their parents' education.

Anxiety is defined by Spielberger, (1983; p. 15) as a "subjective feeling of tension, apprehension, nervousness, and worry associated with an arousal of autonomic nervous system" (cited in Horwitz, Horwitz \& Cope, 1991, p. 27). Abu-Rabia $(2004,711)$ defines anxiety as "fear, panic, and worry". Anxiety is usually divided into three different types:

1. Trait anxiety, which is a personality trait (Eysenck, 1979)

2. State anxiety, which is apprehension experienced at a particular moment in time 
3. Situational anxiety, which is anxiety experienced in a well-defined situation (MacIntyre \& Gardner, 1991a)

A feeling of nervousness associated with language learning is termed as language anxiety (LA). MacIntyre (1998) conceives of LA as "the worry and negative emotional reaction aroused when learning or using a second language" (p. 27). According to Abu-Rabia (2004), "the foreign language learner characterized as having anxiety is usually worried, physically insecure, and unable to engage in situational learning" (p.712).

Second and foreign language researchers and linguists have long been trying to associate anxiety with language learning, in general, as well as in a classroom situation. The anxiety experienced in a classroom is called Foreign Language Classroom Anxiety (FLCA). Horwitz, et al. (1991) views FLCA as "a distinct complex of selfperceptions, beliefs, feelings, and behaviours related to classroom language learning arising from the uniqueness of the language learning process" (p. 31). MacIntyre and Gardner (1991a) and Horwitz, Horwitz and Cope (1986) consider FLCA to be a situational anxiety rather than a trait anxiety which learners experience in the well-defined situation of a foreign language classroom.

In terms of different stages of the language learning process, specifically in a classroom situation, Williams and Andrade (2008) discuss these stages as input, processing (mental planning), and output. Input and processing stages are concerned with the worries, confusions and thinking process of the learners in responding when called for participation in the classroom situation, whereas the output stage is concerned with the actual response of the learners. The researchers have pointed out the effects of LA on each of these stages as well. Other researchers in their studies have also investigated the effect of induced anxiety during each of these stages (Bailey, Onwuegbuzie, \& Daley, 2000; Onwuegbuzie, Bailey, \& Daley, 1999).

For the past many years, a growing body of researchers and theorists has been working on foreign language classroom anxiety in relation to the learners' achievement as well as on the sources of anxiety (Bailey, et al. 2000; Cheng, 2001; Horwitz, Horwitz, \& Cope, 1986; MacIntyre \& Gardner, 1991 a, 1991b; Onwuegbuzie, et al. 1999). Many of the researchers agree that FLA affects students' attitudes and their achievement in language learning. Although anxiety may sometimes be facilitating, in most cases, it negatively affects learners' achievement and leaves its debilitating effects on students' learning. Zheng (2008) asserts that language learning experience could become a traumatic experience and may deeply disturb one's self-esteem or self-confidence as a learner. Anxiety has been proven to negatively affect achievement in the second language learning (Aida, 1994; MacIntyre and Gardener, 1991b). It is true that FLCA affects learners' achievement, but it does not work in isolation. Many other different factors contribute in the emergence of such feelings of anxiety and nervousness. According to Horwitz et al. (1991), possible causes of FLCA are communication apprehension, test anxiety and fear of negative evaluation. The researchers like Aida (1994) Horwitz and his colleagues (1986), have emphasized the importance of teacher-student relationship in the increase and decrease of learners' anxiety levels. Young (1991) reviewed literature and summarized six possible sources of second language anxiety: (1) personal and interpersonal issues, (2) instructorlearner interactions, (3) classroom procedures, (4) language testing, (5) instructor beliefs about language learning, and (6) learner beliefs about language learning. Chan \& Wu (2004) emphasize that "In addition to task difficulty, factors such as teachers' attitude and evaluation, teacher-students interactions in class, parents' expectations, classmates' attitudes, students' own achievements are the potential sources of students' foreign language anxiety" (p. 290). Apart from these factors, anxiety is also correlated with age (Bailey, et al., 2000), motivation (Yan, \& Horwitz, 2008), emotional intelligence (Awan, Sabir \& Iqbal, 2009), and with leaning difficulties (Chen \& Chang, 2004).

The scenario is quite critical in Pakistan as we can observe a large number of failures at the intermediate level due to English only. Overall result of Board of Intermediate and Secondary Education Sargodha for intermediate classes in the year 2009 is $52.79 \%$. The result of the English subject for the same year (both regular and private candidates) is $53.45 \%$. (BISE, 2009). The result of other examination boards in the Punjab is almost the same which means that students find it hard to learn English as a foreign language. The medium of instruction is changed from Urdu to English at the undergraduate level. Moreover, at this level, students are required to study four courses of English reading/writing, speaking and listening, equal to 12 credit hours. In such circumstances Foreign Language Anxiety, recognized as an effective factor in foreign language learning (Piniel, 2006), needs further investigation. 


\section{RESEARCH QUESTIONS}

The following questions are addressed in the present research:

1. What is the relationship between LA and achievement of the students?

2. What is the level of anxiety in undergraduate students with respect to their gender, their background (rural/urban) and parents' education?

3. What specific classroom situations (cause) provoke anxiety during different stages of the language learning process?

\section{METHOD}

The population of this research included all undergraduate students registered in 25 departments of University of Sargodha. The sample consisted of $2^{\text {nd }}$ and $6^{\text {th }}$ semester students from five randomly selected departments. The questionnaire was delivered to 175 students in February-March 2009. Subjects for this study were the students enrolled in English reading, listening and speaking classes in second semester. Students of the sixth semester had already done these courses in the first through fourth semesters. A group of 149 students participated in this study. Twenty six students did not return the questionnaire. Of the 149 students, 65 (43\%) were male and 85 $(57 \%)$ were female.

The questionnaire used in this study was the Foreign Language Classroom Anxiety Scale (FLCAS) designed by Horwitz et al. (1986) for assessing students' anxiety in English classes. An abbreviated version consisted of 17 items (5-point Likert scale: $1=$ Strongly Disagree, $2=$ Disagree, $3=$ Neither Agree nor Disagree, 4 = Agree, $5=$ Strongly Agree) ) was used. The questions were tested with a group of 30 second-semester undergraduate students. Based on the results of pilot testing, revisions were made. The reliability coefficient for the FLCAS (Cronbach alpha) was .774 $(n=149)$. In order to measure causes of anxiety, an inventory used by Williams \& Andrade, (2008) was also employed. Students' grade point average in English classes was taken to find its relationship with LA.

\section{RESULTS}

Table 1: Pearson r, Critical Value, and R-Square of LA and Academic Achievement

\begin{tabular}{lcccc}
\hline LA and Academic Achievement & $\mathbf{N}$ & Correlation & Sig & R-Square \\
\cline { 2 - 5 } & 149 & $-.273^{* *}$ & .001 & 0.075 \\
\hline
\end{tabular}

** Correlation is significant at the 0.01 level (2-tailed).

Table 1 shows the relationship value $(r=-.273, \mathrm{p}<0.01)$ between LA and Academic Achievement which is in expected direction; i.e., negative correlation, which means as the level of anxiety increases, the academic achievement decreases.

Table 2: N, Mean, Standard Deviation, and t Test of Students' LA, in 2nd and 6th Semesters, Male and Female, and Rural and Urban students

\begin{tabular}{lcccccccc}
\hline \multicolumn{1}{c}{ Variables } & Mean & N & SD & $\boldsymbol{T}$ & Df & Sig. (2-tailed) & Mean Difference & Std. Error difference \\
\hline Male & 37.1875 & 64 & 8.28 & 2.520 & 139.541 & .013 & 3.54044 & 1.40500 \\
Female & 33.6471 & 85 & 8.76 & & & & & 1.54099 \\
\hline Rural & 35.5937 & 60 & 9.02 & .314 & 116.634 & .754 & .48402 & 1.65085 \\
Urban & 34.8471 & 89 & 8.50 & & & & & -1.68243 \\
Semester 2 & 34.7500 & 112 & 8.61 & -1.019 & 147 & .310 & & \\
Semester 6th & 36.4324 & 37 & 9.01 & & & & & \\
\hline
\end{tabular}


Table 2 makes it clear that male students are more anxious than females and $t$ test $(t=2.520, p=.013)$ of mean difference shows that this difference is statistically significant. It also shows that the students with a rural background are more anxious than those students who have an urban background, but the difference is not significant ( $t=.314, p=.754)$. The table also reveals that students in the sixth semester are more anxious than those in the second semester, but this difference $(t=-1.019, p=.310)$ is statistically non-significant.

Table 3: Mean, SD and One-Way ANOVA for Language Anxiety and Parents' Education

\begin{tabular}{|c|c|c|c|c|c|c|c|c|c|c|c|}
\hline $\begin{array}{l}\text { Mother's } \\
\text { Education }\end{array}$ & Mean & $\mathbf{N}$ & SD & $\boldsymbol{F}$ & Sig. & $\begin{array}{l}\text { Father's } \\
\text { Education }\end{array}$ & Mean & $\mathbf{N}$ & SD & $\boldsymbol{F}$ & Sig \\
\hline Illiterate & 38.79 & 33 & 7.81 & 2.317 & .060 & Matric \& less & 38.21 & 34 & 7.54 & 2.124 & .100 \\
\hline Matric & 35.11 & 36 & 8.97 & $(4,144)$ & & FA & 35.30 & 40 & 9.81 & $(3,145)$ & \\
\hline FA & 32.28 & 25 & 7.67 & & & BA & 33.81 & 36 & 8.51 & & \\
\hline $\mathrm{BA}$ & 34.28 & 29 & 9.71 & & & $\mathrm{MA} / \mathrm{PhD}$ & 33.64 & 39 & 8.25 & & \\
\hline $\mathrm{MA} / \mathrm{PhD}$ & 34.42 & 26 & 8.30 & & & Total & 35.17 & 149 & 8.71 & & \\
\hline Total & 35.17 & 149 & 8.70 & & & & & & & & \\
\hline
\end{tabular}

Table 3 shows that students whose parents are illiterate or less educated are more anxious than students whose parents are more educated; but the mean difference between the groups is negligible as $F$ test for Fathers' Education $(F(4,144) 2.317, p=.060)$ and for Mothers' Education $(F(3,145) 2.124, p=.100)$ in non-significant.

Table 4a: Mean, N, Standard Deviation and ANOVA of LA in Different Departments

\begin{tabular}{|c|c|c|c|c|c|c|c|c|c|}
\hline Department & Mean & $\mathbf{N}$ & $\begin{array}{c}\text { Std. } \\
\text { Deviation }\end{array}$ & LA & $\begin{array}{c}\text { Sum of } \\
\text { Squares }\end{array}$ & Df & $\begin{array}{c}\text { Mean } \\
\text { Square }\end{array}$ & $\mathbf{F}$ & Sig. \\
\hline Biological Science & 34.07 & 27 & 9.48 & Between Groups & 1054.13 & 4 & 263.53 & 3.733 & .006 \\
\hline Mathematics & 36.11 & 36 & 8.63 & Within Groups & 10166.67 & 144 & 70.60 & & \\
\hline Information Technology & 39.28 & 25 & 8.53 & Total & 11220.80 & 148 & & & \\
\hline BBA & 35.78 & 32 & 8.79 & & & & & & \\
\hline English & 30.79 & 29 & 6.21 & & & & & & \\
\hline Total & 35.17 & 149 & 8.71 & & & & & & \\
\hline
\end{tabular}

Table 4b: LSD Post-Hoc Test of Multiple Comparisons

\begin{tabular}{lcccc}
\hline \multicolumn{1}{c}{ (I) Department } & (J) Department & Mean Difference (I-J) & Std. Error & Sig. \\
\hline Biological sciences & IT & $-5.20593^{*}$ & 2.33216 & .027 \\
Mathematics & English & $5.31801^{*}$ & 2.09660 & .012 \\
BBA & English & $4.98815^{*}$ & 2.15427 & .022 \\
IT & English & $8.48690^{*}$ & 2.29317 & .000 \\
\hline
\end{tabular}

* The mean difference is significant at the 0.05 level.

Table $4 \mathrm{a}$ and $4 \mathrm{~b}$ reveal that students of IT and Mathematics are more anxious compared to English students. One-way ANOVA for mean differences between the departments, in their level of LA, is significant $(\mathrm{F}(4,144)=$ $3.733, \mathrm{p}=.006$ ), which means that students in various departments are significantly different from each other. LSD Post-hoc test of multiple comparisons reveals that the biggest mean differences are found between English and IT. English students are significantly different from BBA, IT and mathematics students. Students of biological sciences are also significantly different from IT. 
Table 5: Frequency and Percentage of Causes of LA as reported by the Students at each stage of Language Learning

\begin{tabular}{cllll}
\hline Item. No & Causes & F & \% age & Category of anxiety \\
\hline 2 & Speaking in front of others & 84 & 55.3 & Output \\
5 & Worried about grammatical mistakes & 71 & 46.7 & Processing \\
11 & Could not respond quickly or smoothly & 69 & 45.4 & Output \\
3 & Worried about pronunciation & 66 & 43.4 & Output \\
8 & Embarrassed to use simple or broken English & 54 & 35.5 & Processing \\
10 & Worried if my English is understood or not & 54 & 35.5 & Output \\
14 & Worried about one's ability level compared to others & 53 & 34.9 & Processing \\
13 & Talking with unfamiliar classmates & 46 & 30.3 & Output \\
6 & Did not know how to respond to the teacher's question & 43 & 28.3 & Processing \\
1 & Did not know how to say something in English & 42 & 27.6 & Processing \\
17 & Had no idea or opinion about the topic & 42 & 27.6 & Processing \\
4 & Being called on by teacher and waiting one's turn & 40 & 26.3 & Input \\
20 & Did not understand long written sentences & 40 & 26.3 & Input \\
12 & Remained silent (mind went blank) & 37 & 24.3 & Processing \\
18 & Misunderstood teacher's question & 36 & 23.7 & Input \\
7 & Confused between English and Urdu & 31 & 20.4 & Processing \\
9 & Did not understand teacher's question or comment & 31 & 20.4 & Input \\
19 & Did not understand spoken English & 29 & 19.1 & Input \\
15 & Did not understand other students & 27 & 17.8 & Input \\
16 & Talking about personal affairs & 24 & 15.8 & Output \\
\hline
\end{tabular}

In Table 5, the causes of LA are ranked in order of occurrence and 'Speaking in front of others' $(55.3 \%)$ is rated as the biggest cause of anxiety. The next cause pointed out by the respondents $(46.7 \%)$ is 'worries about grammatical mistakes,' followed by pronunciation and being unable to talk spontaneously. All those items involving spoken English at any level are rated as high anxiety producing factors. It is also observed that anxiety is occurring at each stage of language learning. It is occurring most often at the processing and output stages of learning the language since 11 high-ranking items are related to these two stages. The items low in ranking are mostly related to students' understanding of teachers and classmates talk and questions that are related to the input stage of learning.

\section{DISCUSSION}

Based on the results of the correlation analysis, the major finding of the present study is that LA and achievement are negatively related to each other. This result is quite consistent with the previous studies which have shown that the students with higher levels of English LA performed poorly compared to less anxious students (Batumlu and Erden, 2007; Horwitz, 2001; and Macintyre \& Gardner, 1991b). Na (2007, 30) asserts that "Usually, high anxiety can make learners get discouraged, lose faith in their abilities, escape from participating in classroom activities, and even give up the effort to learn a language well. Therefore, the learners with high anxiety often get low achievement and low achievement makes them more anxious about learning."

It is interesting to note that male undergraduates are more anxious than females and this difference is statistically significant. This result shows that female undergraduates are more confident and have greater ability to learn a new language and cope with the feelings of anxiety and nervousness. On the contrary, male students are more inclined to hesitate and feel anxious in the language classroom. Yan and Horwitz (2008) found that most of the people believed that females are better language learners than males. Females are also seen as more talented using language in general, more expressive, and simply hard working. Many other researchers pointed toward the other side of the picture and found that neither students' initial foreign language anxiety, nor their latter FLA differed according to their gender (Batumlu and Erden, 2007; and Dewaele, 2007). Keeping in mind the contrary findings of the above discussed different studies, it could be concluded that further investigation is needed in this area.

It is also evident that the rural students are more anxious than urban students, but the difference is not significant. The majority of rural population is not well educated in Pakistan, so most parents of rural students are illiterate and vice versa. It is normally observed that educated people, on average, have a much stronger approach to 
education than illiterate parents and their children have the privilege of learning much of the English language at home and are consequently less anxious in studying English as a foreign language, so this finding is justified in this context.

Regarding the different departments, the findings show that students in the sixth semester are slightly more anxious than those in the second semester; but this difference is statistically non-significant. The students of IT, Mathematics and BBA are more anxious compared to students in the English and biological science departments. Significant differences are found between English and IT, English and Mathematics, English and BBA, and biological science and IT. One of the reasons for these results could obviously be attributed to the nature of the subjects since English students have a better understanding of the language and the contents of other courses written in the general language, whereas students studying other subjects, such as Mathematics, BBA and IT, have more problems because they do not have a grip on the English language. Moreover, Mathematics, BBA and IT contents are normally written in subject-specific varieties of the language (registers). As far as the learners' interests and tendency to learn English are concerned, they seem to be showing lack of interest in studying English, mainly because their major area of studies is not English language but other subjects like BBA, Math, IT, etc. Lack of interest is another factor causing the undergraduates' feelings of anxiety in overcoming their progress in learning English as we know that interest and dedication to do something can take us away from the boundaries of nervousness and anxiety, thus helping reduce the anxiety level which otherwise plays a debilitative role in language learning.

In this study, almost all 20 given causes are considered as stress factors. This percentage ranges from 55.3\% to $15.8 \%$. The anxiety-provoking experiences described by $55 \%$ of the students involve speaking in the second language in front of others. Students are also worried about grammatical mistakes, pronunciation and being unable to respond quickly, and they rate these factors as the biggest causes of anxiety. It is also observed that students experience uneasiness when learning and thinking in a foreign language (processing stage of learning). The least important causes of anxiety are mainly related to understanding teachers' questions, and peers and teachers talk (input stage of learning). The present study explains that students feel anxious and experience fear of negative evaluation when it comes to saying something in the target language, but they are not much worried about the element of understanding others. The factors high in ranking, which are part of the output stage, are speaking in front of others $(55.3 \%)$, being unable to talk spontaneously (45.4\%), worried about pronunciation (43.4\%), fear of being misunderstood (35.5\%), and talking to unfamiliar classmates (30.3\%). Worries about grammatical mistakes (46.7\%), embarrassment in using broken English (35.5\%) and comparing one's ability with others $(34.9 \%)$ are part of the output stage that depict the fact that anxiety is occurring most often at the processing and output stages.

The reasons for this result could be that students feel anxious speaking in front of others and are worried about making mistakes. The existence of anxiety in the English classrooms can be ascribed to classroom atmosphere (Wang, 2003). In Pakistan, normally teachers are dominating in the classrooms and students usually feel oppressed in the presence of the teacher. The controlled and dominated environment of the English classroom discourages students from participating in classroom activities which further affects their learning process and performance. Initiation of the response becomes all the more difficult in such a situation. Students with higher levels of motivation tend to initiate their responses more quickly and to be correct more often (Gardner, Day, \& Maclntyre, 1992).

To cope with the high-rated anxiety factors, teachers need to promote more positive speaking experiences rather than the anxiety-provoking ones, which may make the students feel relaxed, motivated and confident. Piniel $(2006,54)$ especially highlights the teacher's role as a potentially key factor in inducing students' FLA. He also clarifies the points directly related to concrete events in the foreign language classroom: 1)"the teacher does not clarify why the student is being corrected, 2) the feeling of fear of being corrected by the teacher every time a mistake is made, 3) the teacher posing questions that students have not prepared for, and 4) the fast pace of the lessons".

\section{CONCLUSION}

At the undergraduate level, LA negatively influences students' achievement which means that LA has debilitating effects on learners' achievements/scores. In terms of gender differences, the male students are more 
anxious compared to girls who are less anxious and subsequently are higher scorers. The background of the students is also important in this regard as rural students' achievement is low, LA is high, and vice verse. The results show that anxiety-inducing situations experienced by the learners are the input and processing stages of the learning process. Keeping in mind the findings of the study, the following measures are unavoidable for the improvement of achievement.

First, it is suggested that the classroom environment should be quite friendly, encouraging and motivating. The learners should know that making a mistake is not a matter of life and death and that they are not the only ones making mistakes in learning a foreign language. As Horwitz (1999) indicated, many students are relieved to learn that they are not the only ones experiencing anxiety about learning and using a foreign language. Secondly, it is important to deal with anxiety-provoking situations carefully. Although it is neither practical nor helpful to avoid all anxiety-provoking situations completely, the teachers and course designers should design such teaching activities that can help learners reduce their anxiety. It is only possible when the foreign language teachers are aware of the learners' problems and anxiety-provoking situations, as well as having the ability to deal with such situations. Third, the teachers should give more comprehensible input to their students. For this purpose, teachers can reduce their speed of speaking in the class. They may sometimes divert from the target language to the native language of the learners where they find it difficult to understand in the foreign language. In short, we may say it is the teacher's job to help learners minimize their anxiety and keep it at a moderate pace which can motivate learners to perform better in their language classroom.

\section{AUTHOR INFORMATION}

Dr. Riffat-un-Nisa Awan is currently working as Assistantt Professor in Department of Education, University of Sargodha, Pakistan. I completed my PhD from University of the Punjab Lahore, Pakistan in 2003 and Post Doctoral research from University of East Anglia UK in 2008. My area of specialization is educational leadership and management. My teaching and administration experience at school level is about 15 years and at university level 7 years.

Ms. Musarrat Azhar is currently working as a lecturer in ELT in the department of Education, university of Sargodha. I did M.Phil in Linguistics from Baha-ud-din Zakiriya University, Multan, Pakistan in 2004. My area of specialization is English Language teaching and learning. I am looking forward for $\mathrm{PhD}$ in linguistics. My teaching experience is about ten years at university and college level.

Dr. Muhammad Nadeem Anwar is working as Assistant Professor in department of Education, University of Sargodha, Pakistan. He did M.Phil. in Teacher Education from Alllama Iqbal Open University, Islamabad, Pakistan. $\mathrm{He}$ did Ph.D. in Education from University Institute of Education \& Research, UAAR. The main areas of his interest are Management, Continuing Education and Teacher education.

Ms. Anjum Naz is currently working as lecturer in department of education as Lecturer since 2006. Previously I had worked in two government colleges while appointed through Punjab Public Service Commission (PPSC) twice. In this way my total teaching experience is seven years. Currently I am engaged in research activities regarding $\mathrm{Ph}$. D. dissertation which has been foreign evaluated. My areas of specialization are educational administration and science education. I have four research papers published ( 2 national \& 2 international) and three submitted in different national and international journals. I have attended five international conferences and presented the research papers there. I am a member of four scientific societies.

\section{REFERENCES}

1. Abu-Rabia, S. (2004). Teachers' Role, Learners' Gender Differences, and FL Anxiety Among SeventhGrade Students Studying English as a FL. Educational Psychology, 24 (5), 711-721.

2. Aida, Y. (1994). Examination of Horowitz, Horowitz, and Cope's construct of foreign language anxiety: The case of students of Japanese. Modern Language Journal, 78 (2), 155-68.

3. Awan, R.N., Sabir, A . \& Iqbal, S. (2009). A Study of Relationship between Foreign Language Anxiety and Emotional Intelligence among University Students. MEAAR, 1(1), 23-36. 
4. Bailey, P., Onwuegbuzie, A. J. \& Daley, C. E. (2000). Correlates of anxiety at three stages of the foreign language learning process. Journal of Language and Social Psychology, 19 (4), 474-490.

5. Batumlu, D. Z. and Erden M. ( 2007). The relationship between foreign language anxiety and English achievement of Yildiz technical university school of foreign languages preparatory students. Journal of theory and practice in education, 3 (1), 24-38.

6. BISE, (2009). Gazette 2009. Board of Intermediate and Secondary Education Sargodha.

7. Chan, D.Y.C. \& Wu, G.C. (2004). A Study of Foreign Language Anxiety of EFL Elementary School Students in Taipei County, Journal of National Taipei Teachers College, 17 (2), 287-320 .

8. Chen, T.U. \& Chang, G.Y. (2004). The Relationship between Foreign Language Anxiety and Learning Difficulties, Foreign Language Annals, 37 (2), 279-289

9. Cheng, Y. (2001). Learners' Beliefs and Second Language Anxiety Concentric: Studies in English Literature and Linguistics, 27(2), 75-90.

10. Dewaele, Jean-Marc (2007) Predicting language learners' grades in the L1, L2, L3 and L4: the effect of some psychological and sociocognitive variables. International Journal of Multilingualism 4 (3): 169-197.

11. Eysenck, M. W. (1979). Anxiety, learning, and memory: A reconceptualization. Journal of Research in Personality, 13, 363-385.

12. Gardner, R.C., Day, J.B., \& Maclntyre, P.O. (1992). Integrative motivation, induced anxiety, and language learning in a controlled environment. Studies in Second Language Learning, 14, 197-214.

13. Horwitz, E. K. (1999). Preface. In D. J. Young (Ed.), Affect in foreign language and second language learning. A practical guide to creating a low-anxiety classroom atmosphere (pp. xi - xiii). Boston: McGraw-Hill.

14. Horwitz, E. K. (2001). Language anxiety and achievement. Annual Review of Applied Linguistics, 21, 112126.

15. Horwitz, E. K., Horwitz, M. B., \& Cope, J. (1986). Foreign language classroom anxiety. Modern Language Journal, 70 (2), 125-32.

16. Horwitz, M. B., Horwitz, E. K., \& Cope, J. (1991). Foreign language classroom anxiety. In E. K. Horwitz \& D. J. Young (Eds.), Language anxiety: From theory and research to classroom implications (pp. 27-39). Englewood Cliffs, NJ: Prentice Hall.

17. MacIntyre, P. D. (1998). Language anxiety: A review of the research for language teachers. In D. J. Young (Ed.), Affect in foreign language and second language learning (pp. 24-45). Boston: McGraw-Hill.

18. MacIntyre, P. D., \& Gardner R. C. (1991a). Anxiety and second language learning: Towards a theoretical clarification. In: E. K. Horwitz \& D. J. Young (Eds.), Language anxiety: From theory and research to classroom implications (pp. 41-54). Englewood Cliffs, New Jersey: Prentice Hall.

19. MacIntyre, P. D., \& Gardner, R. C. (1991b). Language anxiety: Its relationship to other anxieties and to processing in native and second languages. Language Learning, 41, 513-534

20. Na, Zhao (2007). A Study of High School Students' English Learning Anxiety. The Asian EFL Journal, Volume 9, Number 3 22-34

21. Onwuegbuzie, A.J., Bailey, P., Daley, C.E. (1999). Relationship between anxiety and achievement at three stages of learning a foreign language. Perceptual and Motor Skills, 88, 1085-93.

22. Piniel, K. (2006). Foreign language classroom anxiety: A classroom perspective. In M. Nikolov \& J. Horváth (Eds.), UPRT 2006: Empirical studies in English applied linguistics (pp. 39-58). Pécs: Lingua Franca Csoport.

23. Williams, K. E. Andrade, M. R. (2008). Foreign Language Learning Anxiety in Japanese EFL University Classes: Causes, Coping, and Locus of Control. Electronic Journal of Foreign Language Teaching 5, (2), 181-191.

24. Yan, J. X. \& Horwitz, E.K. (2008). Learners' perceptions of how anxiety interacts with personal and instructional factors to influence their achievement in English: A qualitative analysis of EFL learners in China. Language Learning, 58 (1), 151-183.

25. Young, D. J. (1991). Creating a low-anxiety classroom environment: What does language anxiety research suggest? Modern Language Journal, 75, 426-439.

26. Zheng, Y. (2008). Anxiety and Second/Foreign Language Learning Revisited. Canadian Journal for New Scholars in Education, 1, (1), 1-12. 